\title{
АНАЛИЗ АККУМУЛЯЦИИ ГЕНОТОКСИЧЕСКИХ СОЕДИНЕНИЙ ОТДЕЛЬНЫМИ КОМПОНЕНТАМИ БИОГЕОЦЕНОЗОВ ЧЕТЫРЕХ АДМИНИСТРАТИВНЫХ РАЙОНОВ АЛТАЙСКОГО КРАЯ
}

\author{
Е.Ю. Иванова \\ Воронежский государственный университет, Россия \\ Воронежский орган системы экологической сертификаиии, Россия \\ Поступила в редакииюю 8 апреля 2019 г.
}

\begin{abstract}
Аннотация: В статье изложены результаты экспедиции в четыре района Алтайского края. Два из них Рубцовский и Угловский включают территории, пострадавшие от испытаний ядерного оружия на Семипалатинском полигоне. Два других Славгородский и Немецкий характеризуются развитой промышленностью, выбросы которой также могут ухудшать состояние здоровья населения. В ходе экспедиции отбирали пробы почвы, наземных растений, питьевой воды и картофеля. Кроме того, при наличии водоемов отбирали пробы природной воды, донного грунта и водорослей. Все пробы были проанализированы на наличие прямых мутагенов и промутагенных соединений в тесте Эймса сальмонелла/микросомы. Были сделаны выводы о характере накопления генотоксических соединений во всех исследованных компонентах экосистем.
\end{abstract}

Ключевые слова: генотоксические соединения, тест Эймса, мутагены, промутагены, мутагенный индекс, ксенобиотик, аккумуляция.

Analysis of the accumulation of genotoxic compounds by individual components of biogeocenoses of four administrative regions of the Altai Territory

\section{E. Yu. Ivanova}

\begin{abstract}
The article presents the results of the expedition to four regions of the Altai territory. Two of them include Rubtsov and Uglovsky territories affected by nuclear weapons tests at the Semipalatinsk test site. Two other Slavgorod and German are characterized by a developed industry, the emissions of which can also worsen the health of the population. During the expedition, soil, ground plants, drinking water and potatoes were sampled. In addition, in the presence of water bodies, samples of natural water, bottom soil and algae were taken. All samples were analyzed for the presence of direct mutagens and promutagenic compounds in the Ames Salmonella/microsome test. Conclusions were made about the nature of accumulation of genotoxic compounds in all studied components of ecosystems.
\end{abstract}

Key words: genotoxic compounds, Ames test, mutagens, promutagens, mutagenic index, xenobiotic, accumulation.

\section{ВВЕДЕНИЕ}

В настоящее время можно считать доказанным, что неблагоприятное состояние здоровья населения в ряде районов Алтайского края во многом связано с испытанием ядерного оружия на Семипалатинском полигоне [1]. Территория Алтайского края, характеризуется также высоким уровнем

() Иванова Е.Ю., 2019 развития промышленности, неодинаково распределенной по административным районам. Индекс здоровья населения в различных местах не всегда коррелирует с уровнем развития там промышленности и сельского хозяйства $[1,3]$.

Исследования, проведенные в рамках программы ликвидации последствий испытаний ядерного оружия, выявили генетическую нестабильность как среди местного населения, так и в некоторых 
Анализ аккуимуляциигенотоксических соединений отдельными компонентами биогеоценозов четырех административных районов Алтайского края

Таблицуа 1

Исследование в тесте Эймса промутагенной активности образцов, собранных в различных районах Алтайского края ( штамм ТА 98 и ТА 100, + МА)

\begin{tabular}{|c|c|c|c|c|c|c|c|}
\hline Точки отбора проб & Почва & $\begin{array}{c}\text { Наземные } \\
\text { растения }\end{array}$ & Вода & $\begin{array}{c}\text { Донный } \\
\text { грунт }\end{array}$ & $\begin{array}{c}\text { Водо- } \\
\text { росли }\end{array}$ & $\begin{array}{c}\text { Карто- } \\
\text { фель }\end{array}$ & $\begin{array}{c}\text { Питьевая } \\
\text { вода }\end{array}$ \\
\hline \multicolumn{7}{|c|}{ TA 98 } \\
\hline I Новониколаевка & 1,0 & 1,1 & - & - & - & 1,0 & 0,8 \\
\hline Зеленая дубрава & 1,0 & 0,8 & - & - & - & 0,7 & 1,0 \\
\hline Наумовка & $\mathbf{2 , 1}$ & 1,2 & 1,3 & $\mathbf{1 , 8}$ & 0,9 & 1,3 & 0,6 \\
\hline Веселоярск & $\mathbf{2 , 1}$ & 1,1 & $\mathbf{2 , 7}$ & $\mathbf{2 , 2}$ & 1,4 & 1,1 & 1,0 \\
\hline II Топольное & 1,4 & $\mathbf{2 , 0}$ & - & - & - & 1,3 & 0,7 \\
\hline Лаптев лог & 1,1 & 1,2 & 1,3 & $\mathbf{2 , 0}$ & 0,9 & 1,4 & 1,2 \\
\hline III Яровое 1 & $\mathbf{1 , 9}$ & 0,8 & 0,9 & 1,0 & 1,1 & 0,9 & 1,0 \\
\hline Яровое 2 & 1,1 & 1,0 & 0,7 & 0,9 & $\mathbf{2 , 0}$ & 1,1 & 0,8 \\
\hline IV Кусак & 1,1 & 0,3 & 0,6 & 0,9 & 1,2 & $\mathbf{2 , 4}$ & 0,9 \\
\hline Подсосново & 1,3 & 1,0 & 0,7 & 0,8 & 1,3 & 1,0 & 1,0 \\
\hline \multicolumn{7}{|c|}{$\mathbf{T A ~ 1 0 0}$} \\
\hline I Новониколаевка & 0,8 & 0,8 & - & - & - & 0,9 & 0,7 \\
\hline Зеленая дубрава & 1,4 & 1,2 & - & - & - & 1,1 & 1,0 \\
\hline Наумовка & 1,1 & 1,0 & 0,9 & 0,9 & 0,9 & 0,7 & 0,9 \\
\hline Веселоярск & 1,0 & 0,9 & 1,0 & 0,8 & 0,9 & 1,1 & 0,9 \\
\hline II Топольное & 1,1 & 0,7 & - & - & - & 1,3 & 1,2 \\
\hline Лаптев лог & 0,9 & 1,1 & 0,7 & 1,2 & 1,1 & 1,4 & 1,0 \\
\hline III Яровое 1 & 1,2 & 1,3 & 1,0 & 1,1 & 1,4 & 1,0 & 1,3 \\
\hline Яровое 2 & 1,3 & 1,0 & 0,7 & 0,8 & 1,3 & 1,0 & 1,0 \\
\hline IV Кусак & 0,9 & 0,9 & 1,1 & 0,7 & 1,1 & 1,5 & 0,7 \\
\hline Подсосново & $\mathbf{1 , 8}$ & 1,2 & 1,0 & 0,7 & 0,9 & 1,3 & 1,2 \\
\hline
\end{tabular}

популяциях живых организмов на этих территориях $[1,3]$. Цитогенетический анализ не может с достаточной достоверность ответить на вопрос является ли эта нестабильность следствием ионизирующего излучения или вызвана присутствием в среде мутагенных ксенобиотиков.

В проведенной работе мы исследовали присутсвие мутагенных соединений в некоторых компонентах бигеоценозов Алтайского края с помощью теста Эймса, регистрирующего наличие мутагенных и канцерогенных соединений в районах, подвергавшихся действию ядерных испытаний в период с 1949 по 1965 годы.

В июне 2018 года была проведена экспедиция по четырем административным районам Алтайского края: Рубцовскому I (села Новониколаевка, Зеленая Дубрава, Наумовка и город Веселоярск), Угловскому II (села Топольное и Лаптев Лог), Славгородскому III (села Яровое 1 и Яровое 2) и Немецкому IY (села Кусак и Подсосново). В ходе экспедиционных работ отбирались: донный грунт и водоросли (p. Cladofora) из открытых водоемов, почва, высшие растения (Сурепка - Barbarea vulgaris R.Dr. и картофель - Sollanum tuberozum
L.), а также питьевая вода из глубоководных скважин и колонок с целью изучения накопления мутагенных и канцерогенных соединений в различных компонентах биогеоценозов. В ходе второй экспедиции кроме перечисленных образцов также отбирали воду из естественных водоемов.

\section{МЕТОДЫ ИССЛЕДОВАНИЯ}

Экстракцию аккумулированных в образцах ксенобиотиков осуществляли следующим образом:

а) из воды: в делительной воронке встряхивали 2 л воды с 100 мл гексана. Гексановую фракцию упаривали на роторном испарителе и полученный осадок ксенобиотиков растворяли в 1,5 мл диметилсульфоксида (ДМСО);

б) из почвы: 10 г пробы почвы заливали в соотношении 1:5 смесью органических растворителей (ацетон: гексан =1:1) и выдерживали в течение суток. Полученный экстракт сливали в сборную колбу, а процедуру повторяли еще 5-7 раз до получения неокрашенного экстракта; объединенные экстракты упаривали до сухого веса на роторном испарителе и разводили осадок ксенобиотиков в 1,5 мл ДМСО; 
Исследование в тесте Эймса прямой мутагенной активности образцов, собранных в различных районах Алтайского края (штамм ТА 98 и ТА 100, - МА)

\begin{tabular}{|c|c|c|c|c|c|c|c|}
\hline Точки отбора проб & Почва & $\begin{array}{c}\text { Наземные } \\
\text { растения }\end{array}$ & Вода & $\begin{array}{c}\text { Донный } \\
\text { грунт }\end{array}$ & $\begin{array}{c}\text { Водо- } \\
\text { росли }\end{array}$ & $\begin{array}{c}\text { Карто- } \\
\text { фель }\end{array}$ & $\begin{array}{c}\text { Питьевая } \\
\text { вода }\end{array}$ \\
\hline \multicolumn{7}{|c|}{ TA 98 } \\
\hline I Новониколаевка & 0,8 & 0,8 & - & - & - & 0,8 & 0,9 \\
\hline Зеленая дубрава & $\mathbf{2 , 1}$ & 1,3 & - & - & - & 1,1 & 1,0 \\
\hline Наумовка & $\mathbf{1 , 7}$ & 1,3 & 1,4 & 1,5 & 0,9 & 1,4 & 0,9 \\
\hline Веселоярск & 1,4 & 1,5 & 1,6 & 1,3 & 1,2 & 1,4 & 1,5 \\
\hline II Топольное & 1,3 & 1,1 & - & - & - & 0,9 & 0,8 \\
\hline Лаптев лог & 0,9 & 1,0 & 0,9 & 1,1 & 1,0 & 1,1 & 1,0 \\
\hline III Яровое 1 & 1,2 & 1,3 & 1,0 & 1,1 & 1,4 & 1,0 & 1,3 \\
\hline Яровое 2 & 1,3 & 1,0 & 0,7 & 0,8 & 1,3 & 1,0 & 1,0 \\
\hline IV Кусак & $\mathbf{2 , 0}$ & 1,3 & 0,7 & $\mathbf{3 , 1}$ & 1,2 & $\mathbf{4 , 2}$ & 1,0 \\
\hline Подсосново & $\mathbf{2 , 0}$ & 1,1 & 1,2 & $\mathbf{2 , 1}$ & $\mathbf{1 , 9}$ & $\mathbf{1 , 8}$ & 1,2 \\
\hline \multicolumn{7}{|c|}{$\mathbf{T A} \mathbf{1 0 0}$} \\
\hline I Новониколаевка & 0,9 & 0,7 & - & - & - & 0,9 & 0,7 \\
\hline Зеленая дубрава & 1,4 & 1,2 & - & - & - & 1,1 & 1,0 \\
\hline Наумовка & 1,1 & 1,0 & 0,9 & 0,9 & 0,9 & 0,7 & 0,9 \\
\hline Веселоярск & 1,0 & 0,9 & 1,0 & 0,8 & 0,9 & 1,1 & 0,9 \\
\hline II Топольное & 1,1 & 0,7 & - & - & - & 1,3 & 1,2 \\
\hline Лаптев лог & 0,9 & 1,1 & 0,7 & 1,2 & 1,1 & 1,4 & 1,0 \\
\hline III Яровое 1 & 1,0 & 1,1 & 1,0 & 1,1 & 1,4 & 1,0 & 1,3 \\
\hline Яровое 2 & 1,1 & 1,0 & 0,8 & 1,2 & 1,0 & 1,1 & 1,2 \\
\hline IV Кусак & 0,9 & 0,8 & 0,9 & 1,1 & 1,0 & 1,2 & 0,9 \\
\hline Подсосново & $\mathbf{2 , 1}$ & 1,1 & 1,0 & 0,9 & 1,3 & 1,0 & 1,0 \\
\hline
\end{tabular}

в) из растений: 1-2 г навески сухого материала заливали в соотношении 1:5 смесью органических растворителей (ацетон:гексан = 1:1) и далее экстрагировали ксенобиотики по схеме, описанной в пункте б; полученный осадок растворяли в $1: 5$ мл ДМСО.

Подготовленные таким образом пробы исследовали на наличие в них мутагенной активности в тесте Эймса сальмонелла/микросомы, который позволяет выявлять активность прямых мутагенов (-MA), а также и промутагенных соединений (+МА), проявляющих свое действие только после метаболических превращений в ферментной системе цитохрома Р-450 печени $[6,4]$. В опыте использовали монооксигеназную систему печени крыс, моделируя тем самым ситуацию, возникающую после попадания исследуемых ксенобиотиков в организм млекопитающего. В эксперименте использовали штаммы сальмонеллы ТА 98, вызывающий мутации типа сдвига рамки считывания, и ТА 100 - типа замены оснований.

\section{ОБСУЖДЕНИЕ РЕЗУЛЬТАТОВ}

Результаты экспериментов приведены в виде мутагенных индексов (МИ), отражающих отноше- ние числа колоний ревертантов сальмонеллы, выросших в присутствии экстрактов из исследуемых образцов, к таковому в присутствии растворителя, применяемого для внесения выделенных мутагенных соединений в инкубационную среду теста Эймса. Мутагенный эффект считали значимым для МИ, не ниже 1,7 [4].

Полученные результаты представлены в таблицах 1, 2. Видно, что во всех компонентах биогеоценозов наиболее активно накапливаются прямые мутагены типа сдвига рамки считывания (TA 98, -MA).

Способность аккумулировать генотоксические соединения донных отложений коррелирует с таковой почв. Экстракты проб донного грунта обнаруживают как прямую так и промутагенную активность типа сдвига рамки считывания.

В экстрактах проб питьевой воды также лишь в одном случае (с. Яровое 2 Славгородского района) было обнаружено наличие прямых мутагенов.

Значительная загрязненность почвы и донных отложений генотоксическими соединениями во всех исследованных районах свидетельствует о сильной зашлакованности этих компонентов био- 
Анализ аккуимуляциигенотоксических соединений отдельными компонентами биогеоценозов четырех административных районов Алтайского края

Таблица 3

Частота (\%) обнаружения мутагенного эффекта типа сдвига рамки считывания (ТА 98) и замены оснований (TA 100) среди исследованных образцов, отобранных в Рубцовском (I), Угловском (II), Славгородском (III), и Немецком (IV) районах Алтайского края

\begin{tabular}{|c|c|c|c|c|c|c|c|c|}
\hline \multirow{2}{*}{ Проба } & \multicolumn{4}{|c|}{ TA98 } & \multicolumn{4}{|c|}{ TA100 } \\
\hline & I & II & III & IV & I & II & III & IV \\
\hline & \multicolumn{8}{|c|}{ Сумма прямых и промутагенных соединений } \\
\hline Почва & 50 & 0 & 25 & 50 & 0 & 0 & 0 & 50 \\
\hline $\begin{array}{l}\text { Наземные } \\
\text { растения }\end{array}$ & 0 & 25 & 0 & 0 & 0 & 0 & 0 & 0 \\
\hline Картофель & 0 & 0 & 0 & 75 & 0 & 0 & 0 & 0 \\
\hline Питьевая вода & 0 & 0 & 0 & 0 & 0 & 0 & 0 & 0 \\
\hline Донный грунт & 50 & 50 & 0 & 50 & 0 & 0 & 0 & 0 \\
\hline Вода & 25 & 0 & 0 & 0 & 0 & 0 & 0 & 0 \\
\hline Водоросли & 0 & 0 & 25 & 25 & 0 & 0 & 0 & 0 \\
\hline $\begin{array}{l}\text { Прямые } \\
\text { мутагены }\end{array}$ & 50 & 0 & 0 & 100 & 0 & 0 & 0 & 50 \\
\hline Промутагены & 50 & 0 & 25 & 0 & 0 & 0 & 0 & 50 \\
\hline
\end{tabular}

геоценозов ксенобиотиками, которые попадают туда по-видимому в результате сельскохозяйственного производства. Возможен также перенос мутагенных ксенобиотиоков с воздушными массами или осадками из других районов, характеризующихся повышенным выбросом этих соединений.

Для оценки накопления генотоксических соединений различными компонентами биогеоценозов полученные результаты можно представить в виде отношения мутагенных проб к общему числу исследованных проб (таблица 3).

\section{ЗАКЛЮЧЕНИЕ}

Таким образом, анализ таблиц 2, 3 позволяет сделать следующие выводы.

1. Наиболее часто встречаются прямые мутагены типа сдвига рамки считывания.

2. Почва и донные отложения во всех исследованных районах активно накапливают генотоксические соединения.

3. Пищевые продукты (картофель и питьевая вода) в исследованных населенных пунктах содержали мутагенные ксенобиотики только в Славгородском и Немецком районах. Причем, если экстракты питьевой воды из обоих районов и картофеля из Немецкого района в детоксицирующей системе млекопитающих (вариант +МА) полностью инактивируются, то экстракты картофеля из Славгородского района обезвреживаются менее чем наполовину. В целом же в Немецком районе обнаружены только прямые мутагены в количестве большем, чем в других исследованных районах, но совсем не выявлены промутагенные ксенобиотики.
4, Суммарная частота встречаемости мутагенных проб обоих типов к общему числу исследованных проб мало различается во всех четырех районах. В Рубцовском и Славгородском районах, характеризующихся наиболее развитым промышленным производством, этот индекс лишь немного выше чем в Угловском и Немецком. Такое же соотношение характерно для экстрактов проб почвы, которая наиболее активно аккумулирует мутагенные ксенобиотики.

\section{СПИСОК ЛИТЕРАТУРЫ}

1. Медико-демографический анализ здоровья населения сельских районов Алтайского края на основе изучения индикаторной патологии за 40-летний период (1950-1989 гг.) / В. Б. Колядо [и др.] ; ред. Я. Н. Шойхет. - Барнаул : [б. и.], 1993. - 167 с. - (Ядерные испытания, окружающая среда и здоровье населения Алтайского края : материалы научных исследований; Т. 4, ч. 2).

2. О распределении канцерогенных углеводородов в пресноводных водоемах / А. П. Ильницкий [и др.] // Канцерогенные вещества в окружающей среде / под ред. А. П. Ильницкого. - Москва, 1979. - С. 32-36.

3. Сусков И. И. Цитогенетический и генетико-биохимический мониторинг населения Алтайского края / И. И. Сусков // Ядерные испытания, окружающая среда и здоровье населения Алтайского края : материалы научных исследований. - Барнаул, 1993. - Т. 6. C. $150-168$.

4. Тест-система для оценки загрязненности среды на Salmonella : методические указания / Л. М. Фонштейн [и др.]. - Москва : Издательство МГУ, 1977. - 107 с.

5. Ames B. N. Method for detecting carcinogens and mutagenes with the salmonella/mammalian microsomes 
mutagenicity test / B. N. Ames, J. Mc. Cann, E. Jamasaki // Mutation Research. - 1975. - Vol. 31. - P. 347-364.

6. Carcinogens are mutagenes: a simple test-system combining liver homogenates for activation and bacteria for detection / B. N. Ames [et al.] // Proceedings of the National Academy of Sciences of the USA. - 1973. Vol. 70, № 8. - P. 2281-2285.

7. Kotelevtsev S. V. Biomonitoring of Genotoxicity in Coastal Waters / S. V. Kotelevtsev, L. I. Stepanova, V. M. Glaser // Biomonitoring of coastal waters and estuaries / ed. by K. J. M. Kramer. - Boca Raton, 1994. Chapter 10. - P. 227-245.

\section{REFERENCES}

1. Mediko-demograficheskiy analiz zdorov'ya naseleniya sel'skikh rayonov Altayskogo kraya na osnove izucheniya indikatornoy patologii za 40-letniy period (19501989 gg.) / V. B. Kolyado [i dr.] ; red. Ya. N. Shoykhet. Barnaul : [b. i.], 1993. - 167 s. - (Yadernye ispytaniya, okruzhayushchaya sreda i zdorov'e naseleniya Altayskogo kraya : materialy nauchnykh issledovaniy; T. 4, ch. 2).

2. O raspredelenii kantserogennykh uglevodorodov $\mathrm{v}$ presnovodnykh vodoemakh / A. P. Il'nitskiy [i dr.] // Kant-

\section{Иванова Екатерина Юрьевна}

кандидат биологических наук, доцент кафедры геоэкологии и мониторинга окружающей среды факультета географии, геоэкологии и туризма Воронежского государственного университета, г. Воронеж, т. (473) 266-56-54, E-mail: ivanova.vsu@ gmail.com serogennye veshchestva v okruzhayushchey srede / pod red. A. P. Il'nitskogo. - Moskva, 1979. - S. 32-36.

3. Suskov I. I. Tsitogeneticheskiy i genetiko-biokhimicheskiy monitoring naseleniya Altayskogo kraya / I. I. Suskov // Yadernye ispytaniya, okruzhayushchaya sreda i zdorov'e naseleniya Altayskogo kraya : materialy nauchnykh issledovaniy. - Barnaul, 1993. - T. 6. - C. 150-168.

4. Test-sistema dlya otsenki zagryaznennosti sredy na Salmonella : metodicheskie ukazaniya / L. M. Fonshteyn [i dr.]. - Moskva : Izdatel'stvo MGU, 1977. - 107 s.

5. Ames B. N. Method for detecting carcinogens and mutagenes with the salmonella/mammalian microsomes mutagenicity test / B. N. Ames, J. Mc. Cann, E. Jamasaki // Mutation Research. - 1975. - Vol. 31. - P. 347-364.

6. Carcinogens are mutagenes: a simple test-system combining liver homogenates for activation and bacteria for detection / B. N. Ames [et al.] // Proceedings of the National Academy of Sciences of the USA. - 1973. Vol. 70, № 8. - P. 2281-2285.

7. Kotelevtsev S. V. Biomonitoring of Genotoxicity in Coastal Waters / S. V. Kotelevtsev, L. I. Stepanova, V. M. Glaser // Biomonitoring of coastal waters and estuaries / ed. by K. J. M. Kramer. - Boca Raton, 1994. - Chapter 10. - P. 227-245.

Ivanova Ekaterina Yurievna

Candidate of Biological Sciences, Associate Professor, Department of Geoecology and environmental monitoring of the faculty of geography, Geoecology and tourism, Voronezh State University, Voronezh, tel. (473) 266-56-54,

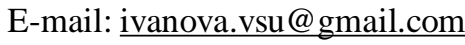

